Article

\title{
Quercetin Impacts Expression of Metabolism- and Obesity-Associated Genes in SGBS Adipocytes
}

\author{
Andreas Leiherer ${ }^{1,2,3,+}$, Kathrin Stoemmer ${ }^{2,+}$, Axel Muendlein ${ }^{1,2}$, Christoph H. Saely ${ }^{1,2,4}$, \\ Elena Kinz ${ }^{1,2}$, Eva M. Brandtner ${ }^{1}$, Peter Fraunberger ${ }^{2,3}$ and Heinz Drexel ${ }^{1,2,4,5, *}$ \\ 1 Vorarlberg Institute for Vascular Investigation and Treatment (VIVIT), Feldkirch A-6800, Austria; \\ andreas.leiherer@vivit.at (A.L.); axel.muendlein@vivit.at (A.M.); christoph.saely@lkhf.at (C.H.S.); \\ elena.kinz@vivit.at (E.K.); lilli.brandtner@vivit.at (E.M.B.) \\ 2 Private University of the Principality of Liechtenstein, Triesen FL-9495, Liechtenstein; \\ kathrin.stoemmer@gmx.de (K.S.); pfraunberger@mzl.at (P.F.) \\ 3 Medical Central Laboratories, Feldkirch A-6800, Austria \\ 4 Department of Medicine and Cardiology, Academic Teaching Hospital Feldkirch, Feldkirch A-6800, Austria \\ 5 Drexel University College of Medicine, Philadelphia, PA 19104, USA \\ * Correspondence: vivit@lkhf.at; Tel.: +43-5522-303-2670; Fax: +43-5522-303-7533 \\ + These authors contributed equally to this work.
}

Received: 19 January 2016; Accepted: 5 May 2016; Published: 12 May 2016

\begin{abstract}
Obesity is characterized by the rapid expansion of visceral adipose tissue, resulting in a hypoxic environment in adipose tissue which leads to a profound change of gene expression in adipocytes. As a consequence, there is a dysregulation of metabolism and adipokine secretion in adipose tissue leading to the development of systemic inflammation and finally resulting in the onset of metabolic diseases. The flavonoid quercetin as well as other secondary plant metabolites also referred to as phytochemicals have anti-oxidant, anti-inflammatory, and anti-diabetic effects known to be protective in view of obesity-related-diseases. Nevertheless, its underlying molecular mechanism is still obscure and thus the focus of this study was to explore the influence of quercetin on human SGBS (Simpson Golabi Behmel Syndrome) adipocytes' gene expression. We revealed for the first time that quercetin significantly changed expression of adipokine (Angptl4, adipsin, irisin and PAI-1) and glycolysis-involved (ENO2, PFKP and PFKFB4) genes, and that this effect not only antagonized but in part even overcompensated the effect mediated by hypoxia in adipocytes. Thus, these results are explained by the recently proposed hypothesis that the protective effect of quercetin is not solely due to its free radical-scavenging activity but also to a direct effect on mitochondrial processes, and they demonstrate that quercetin might have the potential to counteract the development of obesity-associated complications.
\end{abstract}

Keywords: quercetin; phytochemicals; enolase 2; ENO2; angiopoietin-like 4; ANGPTL4; plasminogen activator inhibitor-1; PAI-1; SERPINE1; phosopho-fructokinase; PFKP; 6-phosphofructo-2-kinase/fructose-2,6-biphosphatase 4; PFKFB4; complement factor D; adipsin; CFD; fibronectin type III domain-containing 5; irisin; FNDC5; interleukin-1 $\beta$; IL1B

\section{Introduction}

Obesity confers a high risk of developing numerous metabolic and cardiovascular complications. In the context of extensively growing or prevailing adipose tissue, biochemical and cellular changes take place in adipocytes, in the presence of reduced oxygen supply [1]. Hypoxia is a major starting point of the inflammatory process in adipose tissue and modulates adipocyte metabolism [2-5]. Insufficient oxygen supply is sensed via the mitochondrial electron transfer chain and thus reactive oxygen species (ROS) production is extremely elevated leading to stabilization of hypoxia inducible 
transcription factors [6], thereby taking over the key role in the activation of signaling pathways that are relevant for further metabolic adaptation and adipokine secretion in adipocytes resulting in a dysfunction of adipose tissue [7]. There is evidence that this dysregulation of metabolism in adipose tissue under hypoxia promotes insulin resistance and dyslipidemia and consequently initiates the development of diabetes and cardiovascular disease $[2,8]$.

For that reason, there is growing interest worldwide in plant compounds with respect to their potential to combat obesity and subsequent diseases. Among the more than 4000 flavonoids [9] quercetin is the most common one. Found in fruits, vegetables, wine, tea, and nuts, it represents a central part of our diet [10]. It is regarded as the most effective scavenger of ROS [11] as well. Molecular effects of this phytochemical are poorly understood, although the mitochondrial membrane seems to play a major role herein [10]. The present work was aimed at elucidating the effect of quercetin on the expression of adipokine, glycolytic, and inflammatory genes in hypoxic human Simpson Golabi Behmel Syndrome (SGBS) adipocytes.

\section{Materials and Methods}

\subsection{Cell Culture and Reagents}

Human SGBS preadipocytes were kindly provided by Dr. M. Wabitsch [12] and have been cultivated as described previously [12]. Briefly, cells were maintained in $15 \mathrm{~mL}$ DMEM/Ham's F12 (1:1) medium (Invitrogen, Paisley, UK) containing 10\% fetal calf serum (FCS; Invitrogen), $100 \mathrm{U} / \mathrm{mL}$ penicillin (Invitrogen), $100 \mu \mathrm{g} / \mathrm{mL}$ streptomycin (Invitrogen), $33 \mu \mathrm{M}$ biotin, and $17 \mu \mathrm{M}$ pantothenate. To differentiate SGBS cells into adipocytes, near confluent cells were washed three times with phosphate buffered saline (PBS) and cultured in FCS-free differentiation medium: DMEM/Ham's F12 (1:1) medium supplemented with $100 \mathrm{U} / \mathrm{mL}$ penicillin, $100 \mu \mathrm{g} / \mathrm{mL}$ streptomycin, $33 \mu \mathrm{M}$ biotin, $17 \mu \mathrm{M}$ pantothenate, $10 \mu \mathrm{g} / \mathrm{mL}$ human transferrin, $10 \mathrm{nM}$ insulin, $100 \mathrm{nM}$ hydrocortisone, $0.2 \mathrm{nM}$ triiodothyronine, $25 \mathrm{nM}$ dexamethasone, $500 \mu \mathrm{M}$ 3-isobutyl-1-methylxanthine (IBMX), and $2 \mu \mathrm{M}$ rosiglitazone. After four days, this medium was replaced by differentiation medium excluding dexamethasone, IBMX, and rosiglitazone, which was changed every three to four days. At day 12 after induction of differentiation, $25 \mu \mathrm{M}$ quercetin (Q4951-10G, LOT\#SLBD8415V, Sigma-Aldrich, Steinheim, Germany), dissolved in $23 \mu \mathrm{L}$ DMSO, was added to cell cultures (15 mL), and $23 \mu \mathrm{L}$ DMSO without quercetin was added to control-cultures $(15 \mathrm{~mL})$, resulting in a $0.15 \%(v / v)$ DMSO concentration in all cell cultures. All cell cultures were cultivated for another $48 \mathrm{~h}$ and then exposed to hypoxia. To create a hypoxic environment $\left(1 \% \mathrm{O}_{2}\right)$, cells were placed in a MIC-101 modular incubator chamber (Billups-Rothenberg, Inc., Del Mar, CA, USA), flushed with a mixture of $1 \% \mathrm{O}_{2}, 5 \% \mathrm{CO}_{2}$, and $94 \% \mathrm{~N} 2$, sealed, and incubated at $37^{\circ} \mathrm{C}$. Adipocytes were cultured in hypoxic environment for $16 \mathrm{~h}$, whereas control groups were cultured under normoxic conditions $\left(21 \% \mathrm{O}_{2}\right)$. In total we had four different treatment groups, and each of these approaches consisted of four independent experiments. Reagents were obtained from Sigma-Aldrich unless specified otherwise.

\subsection{Cell Lysis}

Total RNA was prepared from cell samples using the RNeasy Lipid Tissue kit according to the manufacturer's instructions (Qiagen, Hilden, Germany), including the optional DNase step. RNA quantity and purity was determined on NanoDropTM 2000 (Thermo Scientific, Waltham, MA, USA).

\subsection{Quantitative PCR}

RNA was reverse transcribed using the SuperScript III First-Strand Synthesis Kit (Invitrogen) and quantitative PCR (qPCR), was performed using the PowerSYBR ${ }^{\circledR}$ Green PCR Master Mix (Thermo Scientific) on LightCycler ${ }^{\circledR} 480$ System (Roche Diagnostics, Rotkreuz, Switzerland). The primers were synthesized by Microsynth (Balgach, Switzerland) (sequences are disclosed in the supplementary section). A melting curve profile was processed after each run to confirm specific transcripts. 
All reactions were performed in triplicates and the samples were normalized to the endogenous reference TATA-binding protein (TBP) values.

\subsection{Data Analysis}

Results were calculated as cycle threshold values relative to controls according to the $\Delta \Delta \mathrm{Ct}$ method and expressed as fold change (FC, $2^{-\Delta \Delta C t}$ ). Standard deviation of FC (SD) has been calculated according to range for target relative to calibrator resulting from incorporating the standard deviation $\mathrm{s}$ of the $\Delta \Delta \mathrm{Ct}$ values into the fold-difference calculation: $2^{-\Delta \Delta \mathrm{Ct}}$ with $\Delta \Delta \mathrm{Ct}+\mathrm{s}$, and $\Delta \Delta \mathrm{Ct}-\mathrm{s}$. Statistical data analysis was performed using IBM SPSS (version 22, Armonk, NY, USA). Normal distribution of data was confirmed by the Shapiro-Wilks test. To test for significant differences, we used one-way ANOVA to see if there were between-group differences. As there were significant differences in all cases, we proceeded to post-hoc testing by multiple comparison Bonferroni testing. $p$-values smaller than 0.05 were considered significant.

\section{Results}

In the present study we focused on the expression of genes which are known or suspected to be impacted by a hypoxic environment in adipose tissue. In addition, genes were selected based on (i) their role in glucose metabolism and inflammation; (ii) their function as adipokines; and (iii) their role in obesity-associated diseases such as diabetes. These genes were enolase 2 (ENO2), angiopoietin-like 4 (ANGPTL4), plasminogen activator inhibitor-1 (PAI-1, also known as SERPINE1), platelet-type 6-phosophofructokinase (PFKP), 6-phosphofructo-2-kinase/fructose-2,6-biphosphatase 4 (PFKFB4), complement factor D (CFD, also known as adipsin), fibronectin type III domain-containing 5 (FNDC5, which encodes the precursor of irisin), and interleukin-1 $\beta$ (IL1B). Expression of the respective genes was assessed in differentiated, mature SGBS adipocytes, which were cultivated at $37^{\circ} \mathrm{C}$ under normoxia $(\mathrm{N})$ or hypoxia $(\mathrm{H})$ in media supplemented with $(\mathrm{Q})$ or without $25 \mu \mathrm{M}$ quercetin $(\mathrm{C})$ for $16 \mathrm{~h}$. Results of gene expression analysis for the four treatment groups $(\mathrm{CN}, \mathrm{QN}, \mathrm{CH}$, and $\mathrm{QH})$ are summarized in Figure 1 and the supplementary section.

For each gene, mRNA levels were assessed to investigate the effect of quercetin under normoxic cultivation $(\mathrm{QN})$ compared to normoxic cultivation without quercetin $(\mathrm{CN})$, the effect of hypoxic cultivation without quercetin $(\mathrm{CH})$ compared to normoxic cultivation without quercetin $(\mathrm{CN})$, the effect of both quercetin supplementation and hypoxic cultivation $(\mathrm{QH})$ compared to normoxic cultivation without quercetin $(\mathrm{CN})$, and the effect of quercetin under hypoxic cultivation $(\mathrm{QH})$ compared to hypoxic cultivation without quercetin $(\mathrm{CH}$, see supplementary section).

Cultivation of the SGBS adipocytes under hypoxia significantly increased expression of ENO2, PFKP, and PFKFB4 compared to cultivation under normoxia. No significant effect of hypoxia was seen for gene expression of FNDC5/irisin, of adipokines PAI-1 and CFD/adipsin, nor of IL-1 $\beta$ (see supplementary data), though expression of ANGPTL4 was just failing significance $(p=0.057)$. In contrast, after the supplementation of normoxic cultivated culture samples with $25 \mu \mathrm{M}$ quercetin, we observed a significant decrease in the expression of ANGPTL4, CFD/adipsin, PAI-1, and PFKP, compared to normoxic cultivation without quercetin. In samples cultivated under hypoxia and supplemented with quercetin, compared to samples cultivated under hypoxia but without quercetin, we observed a significant decrease in ANGPTL4, CFD/adipsin, PAI-1, and PFKP, and additionally in PFKFB4 and ENO2. The strongest impact of quercetin supplementation, both under normoxic as well as hypoxic conditions, was observed for PFKP, as indicated by a 6.5 fold decrease of gene expression under normoxia $\left(\mathrm{FC}=0.155 ; p=6.9 \times 10^{-6}\right)$ and a 9.2 fold decrease under hypoxia $(\mathrm{FC}=0.109$, $\left.p=2.6 \times 10^{-6}\right)$. When comparing gene expression of quercetin-treated and hypoxic cultivated samples to samples cultivated under normoxia and without quercetin, we still found a significant inhibition of ANGPTL4, CFD/adipsin, PAI-1, and PFKP, whereas FNDC5/irisin, ENO2, and PFKFB4 gene expression was significantly raised instead. 

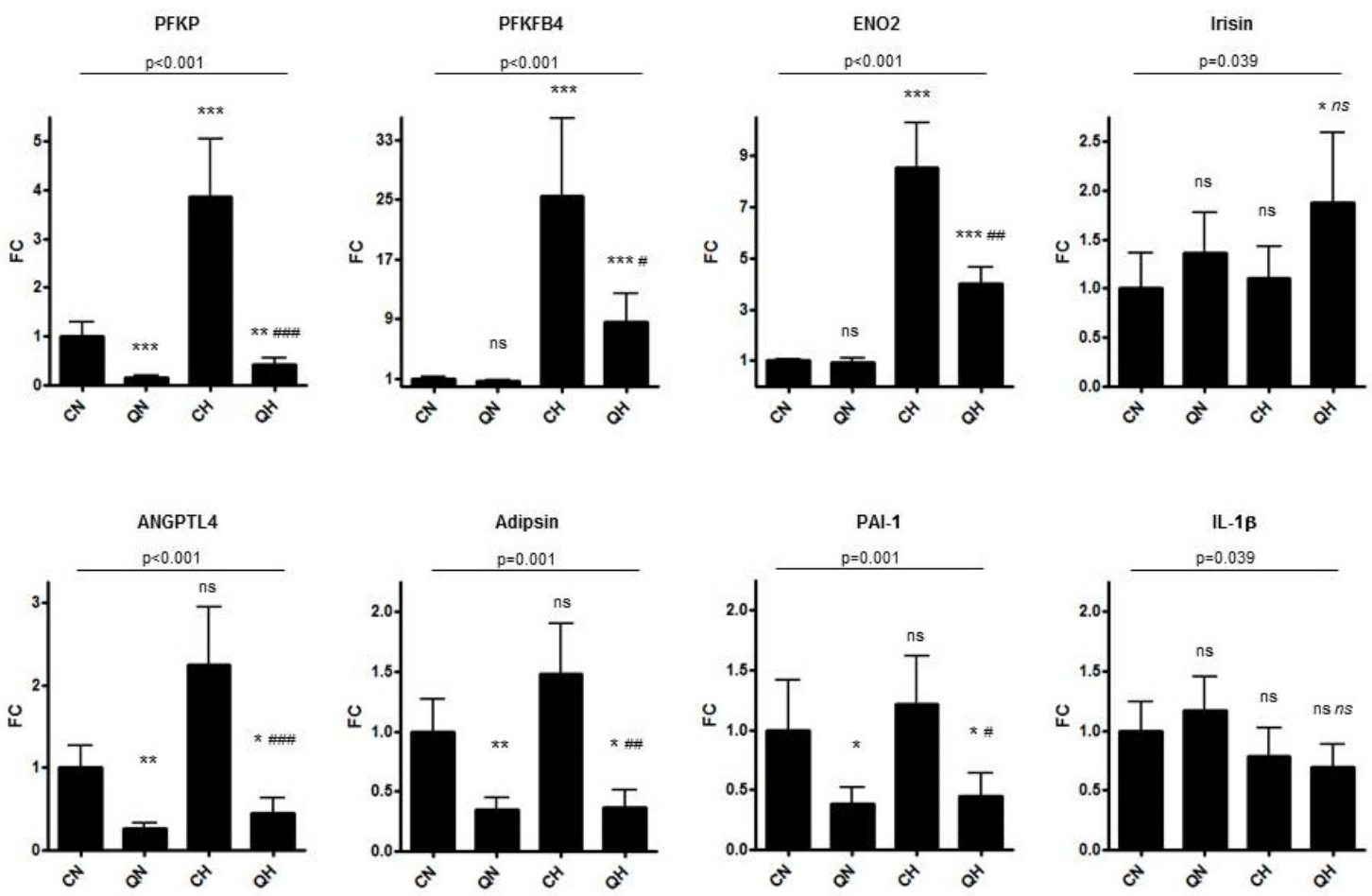

Figure 1. Impact of quercetin on gene transcription of normoxic and hypoxic adipocytes. Levels of mRNA were assessed in SGBS adipocytes cultivated in the presence $(\mathbf{Q})$ or absence of quercetin $(\mathbf{C})$ under normoxic $(\mathbf{N})$ or hypoxic $\left(1 \% \mathrm{O}_{2}\right)$ conditions $(\mathbf{H})$. Transcriptional alterations are expressed as fold change (FC) with standard deviation $\left(2^{-\Delta \Delta \mathrm{ct}}\right.$ with $\Delta \Delta \mathrm{ct}+\mathrm{s}$ and $\Delta \Delta \mathrm{ct}-\mathrm{s}$, where $\mathrm{s}$ is the standard deviation of the $\Delta \Delta$ ct value) relative to cultivation without quercetin in a normoxic atmosphere $(\mathrm{CN})$. All data represent the mean of four independent experiments, each consisting of triplicates. TATA binding protein (TBP) has been used as a reference gene. According to one-way ANOVA, there were significant differences for all gene expression sets with respect to the four treatment groups $(p$-values are indicated). For analyzing differences between two treatment groups post hoc analysis according to Bonferroni was used. A $p$-value $<0.05$, is marked as *, a $p$-value $<0.01$ as $* *$, and a $p$-value $<0.001$ as ${ }^{* * *}$ for the comparison of $\mathrm{QN}, \mathrm{CH}$, or $\mathrm{QH}$ to $\mathrm{CN}$. For the comparison of $\mathrm{QH}$ to $\mathrm{CH}$ a $p$-value $<0.05$ is marked as \#, a $p$-value $<0.01$ as $\#$, and a $p$-value $<0.001$ as \#\#.

\section{Discussion}

This work examined the regulatory impact of quercetin on the gene expression of human SGBS adipocytes. We demonstrated that quercetin is able to significantly decrease gene expression of adipokines ANGPTL4, adipsin, and PAI-1 as well as of glycolysis-associated enzymes ENO2, PFKP, and PFKFB4. Each of these is assumed to be involved in the development of obesity-associated complications.

The most striking effect was observed on the platelet-type 6-phosphofructokinase gene PFKP. It is involved in glycolysis, catalyzing fructose 6-phosphate to fructose1,6-bisphophate conversion. Elevated PFKP expression is known to be associated with increased body mass index (BMI) and obesity $[13,14]$. PFKP enzyme activity is inhibited by ATP, citrate, fatty acids [15], and by new synthetic molecules presently undergoing clinical trials [16,17]. We could clearly demonstrate that its expression is upregulated by hypoxia, which is, most likely, due to a direct binding of HIF-1 $\alpha$ [3] and downregulated by quercetin, whereby the latter effect was predominant when both factors were applied in parallel.

The enolase 2 gene ENO2 is directly involved in glycolysis, catalyzing the reversible conversion of 2-phosphoglycerate to phosphoenolpyruvate. Similar to PFKP, ENO2 gene expression was significantly decreased by quercetin treatment under hypoxic conditions, but in contrast to PFKP, the attenuation by quercetin could not outperform the hypoxia-effect. The same applies to the expression of 
6-phosphofructo-2-kinase/fructose-2,6-biphosphatase gene PFKFB4. It regulates the steady-state concentration of 2,6-bisphosphate, an allosteric activator of phosphofructokinase. Like PFKP and ENO2, it is activated by hypoxia as well [3,18-20]. In metabolic screens PFKFB4 has been proposed as a new potential target in cancer therapy as its silencing increased the ROS level and inhibited survival of cancer cells but not epithelial cells. Thus PFKFB4 seems to be essential to keep balance between glycolytic activity and antioxidant production at least in cancer cells [21]. Whether hypoxia-mediated upregulation of PFKFB4 might prevent ROS overproduction in adipocytes is unknown, but appears contradictory.

The fasting induced adipose factor ANGPTL4 is predominantly produced in adipose tissue. It is a target of peroxisome proliferator-activated receptor (PPAR) $\gamma$ [22] and recently it has been demonstrated to be inhibited by AMP-activated kinase (AMPK) activation [23,24]. It is an important player in energy metabolism and insulin sensitivity and its overexpression elevates triglycerides and total cholesterol and impacts the activity of mitochondrial respiratory chain complexes [25]. Although its role in the context of metabolic diseases is still elusive, ANGPTL4 plasma levels have been reported to be significantly higher in patients with metabolic syndrome and were predictive for future cardiovascular events [26]. In the present study, our data demonstrated a trend for hypoxia-mediated upregulation. Quercetin treatment, in contrast, led to a significant decrease of ANGPTL4 expression and that inhibiting effect was not abolished even in the presence of hypoxia.

Similarly, PAI-1 is also a target of PPAR $\gamma[27,28]$. Quercetin has previously been described to activate AMPK and to decrease PPAR $\gamma$ expression [29]. AMPK activation is known to result in PPAR $\gamma$ inhibition [30-32]. As quercetin also exhibits the ability to decrease ATP production, causing an increase in AMP and the activation of the AMPK signaling pathway [33], a common regulatory mechanism for ANGPTL4 and PAI-1 appears evident. It is presently known that circulating PAI-1 levels are increased in the metabolic syndrome as well, and that they are strongly associated with visceral adiposity and may contribute to the inflammatory state in obesity [34]. Moreover, mice lacking PAI-1 have increased energy expenditure, improved glucose tolerance, enhanced insulin sensitivity, and are resistant to dietor genetically induced obesity. Improvement of insulin sensitivity by weight loss or treatment with insulin sensitizers such as metformin or thiazoladinediones significantly reduces circulating PAI-1 levels [34]. Thus PAI-1 has been considered as a biomarker to predict obesity-associated diseases [35]. Apart from the role as a marker, the PAI-1-PPAR $\gamma$ interaction may also be a potential target for novel anti-obesity drugs. In that context, our findings, which indicate that there is a significant downregulation of PAI-1 expression upon quercetin treatment independent of normoxic or hypoxic cultivation, together with the previously reported PAI-1 downmodulation by resveratrol [36], may be helpful in elucidating the detailed mode of action of these phytochemicals for future clinical use.

Knowledge about the adipokine adipsin, which is encoded by the CFD gene, is very limited. It is the rate-limiting enzyme of the alternative complement pathway, working as serine protease [37], and it is mainly produced by adipocytes [38]. It is known that adipsin levels are associated with BMI, but the way its expression is regulated is presently unknown [39]. In the context of macular degeneration, a decrease of adipsin [40] and an inhibition of the systemic activation of the complement system [41] have both been observed in the plasma of affected patients upon treatment with the anti-oxidant lutein. Whether that anti-oxidant affects gene expression of CFD/adipsin in adipocytes is not known [39]. Here, we are able to describe for the first time a downmodulation of CFD/adipsin by the anti-oxidant quercetin in adipocytes. Thus these results are of broad clinical interest.

FNDC5, primarily identified as a myokine which is cleaved and secreted as irisin from muscle during exercise is known to induce metabolic benefits after exercise [42]. A recent study reported that white adipose tissue in humans and rats is able to express and secrete FNDC5/irisin as well [43]. In line with data from a human trial reporting no effect of hypoxia on irisin levels [44], we also did not observe a significant effect of hypoxic treatment on the expression of FNDC5/irisin in our study. Interestingly, we observed a significant increase of FNDC5/irisin expression by quercetin supplementation under hypoxia and there is, to our knowledge, no other study reporting the impact of phytochemicals on FNDC5/irisin in adipocytes. Of interest, FNDC5 expression is, in contrast to ANGPTL4 and PAI-1, 
known to be elevated by AMPK activation [42]. In line with our data, a similar effect on FNDC5/irisin expression was seen in the hippocampus tissue of rats receiving quercetin leading to a protection against brain damage under hypoxia [45]. Thus these findings may together initiate future studies further elucidating the overall function of irisin in cell types other than myocytes.

We also observed that neither quercetin nor hypoxic cultivation did impact the expression of IL-1 $\beta$. This is, in case of the latter, a bit surprising as hypoxia in adipose tissue is suggested to induce inflammation. However, similar results have been previously reported in human adipocytes $[4,46]$. Drawing conclusions from adipocytes about adipose tissue is problematic and does not take into account the complex in vivo situation with various cell-type interactions involved in triggering and regulating the inflammatory cascade. That issue has been reviewed in detail recently [47].

Quercetin has a radical scavenging capacity [48] and its pure stoichiometric consumption of free radicals by the molecule structure itself has the potential to antagonize hypoxia [49]. Hypoxia is sensed by mitochondria and leads to an increase in ROS generation [6]. ROS overproduction has previously been hypothesized to trigger a couple of independent pathways implicated in metabolism [50]. Such chronic oxidative stress plays a pivotal role in the pathogenesis of degenerative disorders [51]. On a molecular level, the rise of ROS levels leads to the stabilization of HIF-1 [6,52]. Hence the antioxidant capacity of quercetin might be responsible for a decreased expression of HIF-1-dependent genes like PFKFB4 [19], PFKP, and ENO2 [3]. This property of quercetin is in line with the reduced expression of PFKFB4 and ENO2 in our study and resembles the effect of a HIF-inhibitor [3]. However, it does not explain why gene expression in the case of PFKP or ANGPTL4 drops below the control level, outperforming by far the opposed effect of hypoxia. Likewise, the expression of CFD/adipsin and PAI-1 was significantly decreased as well, although hypoxia had only a slight and insignificant effect.

In order to tie all results together, we believe that quercetin action, which not only antagonizes but also outperforms the effect mediated by hypoxia, lies not only in its radical scavenging capacity, but is mainly based on intracellular mechanisms [33]. Quercetin is known to accumulate in mitochondria [53], it has previously been hypothesized by us [10] and has recently become more commonly accepted that quercetin influences the mitochondrial electron transfer chain [33,54]. In addition, this seems to be associated with quercetin's action on mitochondrial biogenesis and apoptosis but also on the mitochondrial permeability transition pore, the membrane potential, and finally ATP generation impacting the AMPK activity [29,45,55-63]. Of interest, Lago et al. have revealed complex I as a target of structural binding by quercetin competing with coenzyme Q [64]. Such a specific effect on the mitochondria may be associated with or causative for further downstream effects on different targets including AMPK activation. Thus the effects of quercetin as seen in our study may be related to its (i) radical scavenging activity which would appear to counteract hypoxia, but also to its (ii) direct binding of the mitochondrial electron transfer chain complexes, probably impacting mitochondrial function including energy homeostasis, which finally leads to the mentioned effects on AMPK-dependent targets.

Nevertheless, we have to mention that the detailed role of quercetin in hypoxic adipose tissue is still elusive and there are several mechanism including the inhibition of the proteasome [65], the modulation of the JNK and ERK pathway as well as AP-1 and NF- $\mathrm{kB}$ activation, and the ambiguous role of PPAR $\gamma[29,66]$ which need further investigation. Moreover, since the potential of human adipose tissue to differentiate is limited, SGBS adipocytes were used. They are a valuable, well established and relevant tool to study human adipocyte biology in vitro [12,67-73]. SGBS adipocytes are derived from the stromal cells fraction of subcutaneous adipose tissue of a patient suffering from Simpson-Golabi-Behmel syndrome, and feature a long lasting and high capacity for adipose differentiation and at the same time display a gene expression pattern similar to mature fat cells $[12,74]$. They have been used to explore the effect of hypoxia on adipose tissue $[3,68,75-78]$ and a comprehensive gene expression and secretome profiling under hypoxic conditions has already been done $[4,79]$. However we cannot exclude that the underlying mutation in the SGBS cells coming 
from the specimen of a diseased patient [67] may impact gene expression in a different way than it would be seen in adipocytes from a healthy subject. Therefore, additional studies using, for example, primary cells derived from lipoaspirates are needed to be performed to further elucidate the relation of whole adipose tissue hypoxia and the chronic inflammation observed in obesity.

Finally, the amount of quercetin used to treat SGBS adipocytes in the present study was $25 \mu \mathrm{M}$ and that concentration was comparable to those from previous in vitro studies [10]. The estimated quercetin intake by Western diet ranges from 0 to $30 \mathrm{mg}$ [80], whereas up to $2000 \mathrm{mg}$ have been administered in clinical trials [10]. However, it has to be mentioned that quercetin bioavailability is low and varies widely between individuals due to endogenous and exogenous factors [81]. The utility of nanoparticles as delivery carriers for quercetin has been recently summarized by Nam et al. (2016) [82]. Such a nanoformulation demonstrates the ability to enhance solubility of quercetin in water, absorption into the body, circulation time, and target specificity. Thus these more stable and long-lived application forms may further release and potentiate quercetin's putative health benefits [82].

In conclusion, this study demonstrated that quercetin is able to antagonize and, in part, to overcome effects mediated by hypoxia. These results are in accordance with the hypothesis recently proposed by de Oliveira et al. suggesting that a direct free radical-scavenging activity of quercetin cannot be concluded as the major mechanism for the clinical effects of quercetin, and that there must be a direct effect in mitochondrial processes [33]. In addition, they further substantiate and elucidate quercetin's anti-diabetic effect and suggest that quercetin may play a protective role counteracting the development of obesity-associated associations.

Supplementary Materials: The following are available online at http:/ www.mdpi.com/2072-6643/8/5/282/s1, Table S1: Oligonucleotide sequences. All sequences are given in $5^{\prime}-3^{\prime}$ orientation, Table S2: Gene expression data according to qPCR analysis.

Acknowledgments: The present study was supported by grants from the Land Vorarlberg.

Author Contributions: A.L., A.M., and H.D. conceived and designed the experiments; A.L. and K.S. performed the experiments; A.L., C.H.S., and K.S. analyzed the data; E.K., E.B., and P.F. contributed reagents/materials/analysis tools; A.L. wrote the paper.

Conflicts of Interest: The authors declare no conflict of interest. The founding sponsors had no role in the design of the study; in the collection, analyses, or interpretation of data; in the writing of the manuscript, and in the decision to publish the results.

\section{References}

1. Pasarica, M.; Sereda, O.R.; Redman, L.M.; Albarado, D.C.; Hymel, D.T.; Roan, L.E.; Rood, J.C.; Burk, D.H.; Smith, S.R. Reduced adipose tissue oxygenation in human obesity: Evidence for rarefaction, macrophage chemotaxis, and inflammation without an angiogenic response. Diabetes 2009, 58, 718-725. [CrossRef] [PubMed]

2. Trayhurn, P. Hypoxia and adipose tissue function and dysfunction in obesity. Physiol. Rev. 2013, 93, 1-21. [CrossRef] [PubMed]

3. Leiherer, A.; Geiger, K.; Muendlein, A.; Drexel, H. Hypoxia induces a HIF-1alpha dependent signaling cascade to make a complex metabolic switch in SGBS-adipocytes. Mol. Cell Endocrinol. 2013, 383, 21-31. [CrossRef] [PubMed]

4. Geiger, K.; Leiherer, A.; Muendlein, A.; Stark, N.; Geller-Rhomberg, S.; Saely, C.H.; Wabitsch, M.; Fraunberger, P.; Drexel, H. Identification of Hypoxia-Induced Genes in Human SGBS Adipocytes by Microarray Analysis. PLoS ONE 2011, 6, e26465. [CrossRef] [PubMed]

5. Mazzatti, D.; Lim, F.L.; O'Hara, A.; Wood, I.S.; Trayhurn, P. A microarray analysis of the hypoxia-induced modulation of gene expression in human adipocytes. Arch. Physiol. Biochem. 2012, 118, 112-120. [CrossRef] [PubMed]

6. Klimova, T.; Chandel, N.S. Mitochondrial complex III regulates hypoxic activation of HIF. Cell Death Differ. 2008, 15, 660-666. [CrossRef] [PubMed]

7. Klöting, N.; Fasshauer, M.; Dietrich, A.; Kovacs, P.; Schon, M.R.; Kern, M.; Stumvoll, M.; Bluher, M. Insulin-sensitive obesity. Am. J. Physiol. Endocrinol. Metab. 2010, 299, E506-E515. [CrossRef] [PubMed] 
8. Apostolopoulos, V.; de Court, S.L.; Blatch, G.L.; Tangalakis, K.; de Court, B. The complex immunological and inflammatory network of adipose tissue in obesity. Mol. Nutr. Food Res. 2015, 60, 43-57. [CrossRef] [PubMed]

9. Hollman, P.C.; van Trijp, J.M.; Buysman, M.N.; van der Gaag, M.S.; Mengelers, M.J.; de Vries, J.H.; Katan, M.B. Relative bioavailability of the antioxidant flavonoid quercetin from various foods in man. FEBS Lett. 1997, 418, 152-156. [CrossRef]

10. Leiherer, A.; Mundlein, A.; Drexel, H. Phytochemicals and their impact on adipose tissue inflammation and diabetes. Vascul. Pharmacol. 2013, 58, 3-20. [CrossRef] [PubMed]

11. Si, H.; Liu, D. Dietary antiaging phytochemicals and mechanisms associated with prolonged survival. J. Nutr. Biochem. 2014, 25, 581-591. [CrossRef] [PubMed]

12. Wabitsch, M.; Brenner, R.E.; Melzner, I.; Braun, M.; Moller, P.; Heinze, E.; Debatin, K.M.; Hauner, H. Characterization of a human preadipocyte cell strain with high capacity for adipose differentiation. Int. J. Obes. Relat. Metab. Disord. 2001, 25, 8-15. [CrossRef] [PubMed]

13. Scuteri, A.; Sanna, S.; Chen, W.-M.; Uda, M.; Albai, G.; Strait, J.; Najjar, S.; Nagaraja, R.; Orr, M.; Usala, G.; et al. Genome-wide association scan shows genetic variants in the FTO gene are associated with obesity-related traits. PLoS Genet. 2007, 3, e115. [CrossRef] [PubMed]

14. Liu, Y.J.; Liu, X.G.; Wang, L.; Dina, C.; Yan, H.; Liu, J.F.; Levy, S.; Papasian, C.J.; Drees, B.M.; Hamilton, J.J.; et al. Genome-wide association scans identified CTNNBL1 as a novel gene for obesity. Hum. Mol. Genet. 2008, 17, 1803-1813. [CrossRef] [PubMed]

15. Ros, S.; Schulze, A. Balancing glycolytic flux: The role of 6-phosphofructo-2-kinase/fructose 2,6-bisphosphatases in cancer metabolism. Cancer Metab. 2013, 1, 8. [CrossRef] [PubMed]

16. Clem, B.; Telang, S.; Clem, A.; Yalcin, A.; Meier, J.; Simmons, A.; Rasku, M.A.; Arumugam, S.; Dean, W.L.; Eaton, J.; et al. Small-molecule inhibition of 6-phosphofructo-2-kinase activity suppresses glycolytic flux and tumor growth. Mol. Cancer Ther. 2008, 7, 110-120. [CrossRef] [PubMed]

17. Granchi, C.; Fancelli, D.; Minutolo, F. An update on therapeutic opportunities offered by cancer glycolytic metabolism. Bioorg. Med. Chem. Lett. 2014, 24, 4915-4925. [CrossRef] [PubMed]

18. Szturmowicz, M.; Burakowski, J.; Tomkowski, W.; Sakowicz, A.; Filipecki, S. Neuron-specific enolase in non-neoplastic lung diseases, a marker of hypoxemia? Int. J. Biol. Markers 1998, 13, 150-153. [PubMed]

19. Minchenko, O.; Opentanova, I.; Minchenko, D.; Ogura, T.; Esumi, H. Hypoxia induces transcription of 6-phosphofructo-2-kinase/fructose-2,6-biphosphatase-4 gene via hypoxia-inducible factor-1alpha activation. FEBS Lett. 2004, 576, 14-20. [CrossRef] [PubMed]

20. Guerin, E.; Raffelsberger, W.; Pencreach, E.; Maier, A.; Neuville, A.; Schneider, A.; Bachellier, P.; Rohr, S.; Petitprez, A.; Poch, O.; et al. In vivo topoisomerase I inhibition attenuates the expression of hypoxia-inducible factor 1alpha target genes and decreases tumor angiogenesis. Mol. Med. 2012, 18, 83-94. [CrossRef] [PubMed]

21. Ros, S.; Santos, C.R.; Moco, S.; Baenke, F.; Kelly, G.; Howell, M.; Zamboni, N.; Schulze, A. Functional metabolic screen identifies 6-phosphofructo-2-kinase/fructose-2,6-biphosphatase 4 as an important regulator of prostate cancer cell survival. Cancer Discov. 2012, 2, 328-343. [CrossRef] [PubMed]

22. Yoon, J.C.; Chickering, T.W.; Rosen, E.D.; Dussault, B.; Qin, Y.; Soukas, A.; Friedman, J.M.; Holmes, W.E.; Spiegelman, B.M. Peroxisome proliferator-activated receptor gamma target gene encoding a novel angiopoietin-related protein associated with adipose differentiation. Mol. Cell Biol. 2000, 20, 5343-5349. [CrossRef] [PubMed]

23. Dijk, W.; Heine, M.; Vergnes, L.; Boon, M.R.; Schaart, G.; Hesselink, M.K.; Reue, K.; Marken Lichtenbelt, W.D.; Olivecrona, G.; Rensen, P.C.; et al. ANGPTL4 mediates shuttling of lipid fuel to brown adipose tissue during sustained cold exposure. Elife 2015, 4, e08428. [CrossRef] [PubMed]

24. Catoire, M.; Alex, S.; Paraskevopulos, N.; Mattijssen, F.; Evers-van Gogh, I.; Schaart, G.; Jeppesen, J.; Kneppers, A.; Mensink, M.; Voshol, P.J.; et al. Fatty acid-inducible ANGPTL4 governs lipid metabolic response to exercise. Proc. Natl. Acad. Sci. USA 2014, 111, E1043-E1052. [CrossRef] [PubMed]

25. Wang, Y.; Lam, K.S.; Lam, J.B.; Lam, M.C.; Leung, P.T.; Zhou, M.; Xu, A. Overexpression of angiopoietin-like protein 4 alters mitochondria activities and modulates methionine metabolic cycle in the liver tissues of db/db diabetic mice. Mol. Endocrinol. 2007, 21, 972-986. [CrossRef] [PubMed] 
26. Muendlein, A.; Saely, C.H.; Leiherer, A.; Fraunberger, P.; Kinz, E.; Rein, P.; Vonbank, A.; Zanolin, D.; Malin, C.; Drexel, H. Angiopoietin-like protein 4 significantly predicts future cardiovascular events in coronary patients. Atherosclerosis 2014, 237, 632-638. [CrossRef] [PubMed]

27. Sawai, H.; Liu, J.; Reber, H.A.; Hines, O.J.; Eibl, G. Activation of peroxisome proliferator-activated receptor-gamma decreases pancreatic cancer cell invasion through modulation of the plasminogen activator system. Mol. Cancer Res. 2006, 4, 159-167. [CrossRef] [PubMed]

28. Pang, X.; Wei, Y.; Zhang, Y.; Zhang, M.; Lu, Y.; Shen, P. Peroxisome proliferator-activated receptor-gamma activation inhibits hepatocellular carcinoma cell invasion by upregulating plasminogen activator inhibitor-1. Cancer Sci. 2013, 104, 672-680. [CrossRef] [PubMed]

29. Ahn, J.; Lee, H.; Kim, S.; Park, J.; Ha, T. The anti-obesity effect of quercetin is mediated by the AMPK and MAPK signaling pathways. Biochem. Biophys. Res. Commun. 2008, 373, 545-549. [CrossRef] [PubMed]

30. Namgaladze, D.; Kemmerer, M.; von Knethen, A.; Brune, B. AICAR inhibits PPARgamma during monocyte differentiation to attenuate inflammatory responses to atherogenic lipids. Cardiovasc. Res. 2013, 98, 479-487. [CrossRef] [PubMed]

31. Leff, T. AMP-activated protein kinase regulates gene expression by direct phosphorylation of nuclear proteins. Biochem. Soc. Trans. 2003, 31, 224-227. [CrossRef] [PubMed]

32. Sozio, M.S.; Lu, C.; Zeng, Y.; Liangpunsakul, S.; Crabb, D.W. Activated AMPK inhibits PPAR-\{alpha\} and PPAR-\{gamma\} transcriptional activity in hepatoma cells. Am. J. Physiol. Gastrointest. Liver Physiol. 2011, 301, G739-G747. [CrossRef] [PubMed]

33. De Oliveira, M.R.; Nabavi, S.M.; Braidy, N.; Setzer, W.N.; Ahmed, T.; Nabavi, S.F. Quercetin and the mitochondria: A mechanistic view. Biotechnol. Adv. 2015. [CrossRef] [PubMed]

34. Badman, M.K.; Flier, J.S. The adipocyte as an active participant in energy balance and metabolism. Gastroenterology 2007, 132, 2103-2115. [CrossRef] [PubMed]

35. Gonzalez, M.; Del Mar, B.M.; Pons, A.; Llompart, I.; Tur, J.A. Inflammatory markers and metabolic syndrome among adolescents. Eur. J. Clin. Nutr. 2012, 66, 1141-1145. [CrossRef] [PubMed]

36. Zagotta, I.; Dimova, E.Y.; Funcke, J.B.; Wabitsch, M.; Kietzmann, T.; Fischer-Posovszky, P. Resveratrol suppresses PAI-1 gene expression in a human in vitro model of inflamed adipose tissue. Oxid. Med. Cell Longev. 2013, 2013, 793525. [CrossRef] [PubMed]

37. Volanakis, J.E.; Narayana, S.V. Complement factor, D. A novel serine protease. Protein Sci. 1996, 5, 553-564. [CrossRef] [PubMed]

38. White, R.T.; Damm, D.; Hancock, N.; Rosen, B.S.; Lowell, B.B.; Usher, P.; Flier, J.S.; Spiegelman, B.M. Human adipsin is identical to complement factor $\mathrm{D}$ and is expressed at high levels in adipose tissue. J. Biol. Chem. 1992, 267, 9210-9213. [PubMed]

39. Tian, Y.; Kijlstra, A.; Webers, C.A.; Berendschot, T.T. Lutein and Factor D: Two intriguing players in the field of age-related macular degeneration. Arch. Biochem. Biophys. 2015, 57, 49-53. [CrossRef] [PubMed]

40. Tian, Y.; Kijlstra, A.; van der Veen, R.L.; Makridaki, M.; Murray, I.J.; Berendschot, T.T. The effect of lutein supplementation on blood plasma levels of complement factor D; C5a and C3d. PLoS ONE 2013, 8, e73387. [CrossRef] [PubMed]

41. Tian, Y.; Kijlstra, A.; van der Veen, R.L.; Makridaki, M.; Murray, I.J.; Berendschot, T.T. Lutein supplementation leads to decreased soluble complement membrane attack complex sC5b-9 plasma levels. Acta Ophthalmol. 2015, 93, 141-145. [CrossRef] [PubMed]

42. Bostroem, P.; Wu, J.; Jedrychowski, M.P.; Korde, A.; Ye, L.; Lo, J.C.; Rasbach, K.A.; Bostrom, E.A.; Choi, J.H.; Long, J.Z.; et al. A PGC1-alpha-dependent myokine that drives brown-fat-like development of white fat and thermogenesis. Nature 2012, 481, 463-468. [CrossRef] [PubMed]

43. Roca-Rivada, A.; Castelao, C.; Senin, L.L.; Landrove, M.O.; Baltar, J.; Belen, C.A.; Seoane, L.M.; Casanueva, F.F.; Pardo, M. FNDC5/irisin is not only a myokine but also an adipokine. PLoS ONE 2013, 8, e60563.

44. Scalzo, R.L.; Peltonen, G.L.; Giordano, G.R.; Binns, S.E.; Klochak, A.L.; Paris, H.L.; Schweder, M.M.; Szallar, S.E.; Wood, L.M.; Larson, D.G.; et al. Regulators of human white adipose browning: Evidence for sympathetic control and sexual dimorphic responses to sprint interval training. PLoS ONE 2014, 9, e90696. [CrossRef] [PubMed] 
45. Liu, P.; Zou, D.; Yi, L.; Chen, M.; Gao, Y.; Zhou, R.; Zhang, Q.; Zhou, Y.; Zhu, J.; Chen, K.; et al. Quercetin ameliorates hypobaric hypoxia-induced memory impairment through mitochondrial and neuron function adaptation via the PGC-1alpha pathway. Restor. Neurol. Neurosci. 2015, 33, 143-157. [PubMed]

46. Famulla, S.; Horrighs, A.; Cramer, A.; Sell, H.; Eckel, J. Hypoxia reduces the response of human adipocytes towards TNFalpha resulting in reduced NF-kappaB signaling and MCP-1 secretion. Int. J. Obes. (Lond.) 2012, 36, 986-992. [CrossRef] [PubMed]

47. Goossens, G.H.; Blaak, E.E. Adipose tissue dysfunction and impaired metabolic health in human obesity: A matter of oxygen? Front. Endocrinol. (Lausanne) 2015, 6, 55. [CrossRef] [PubMed]

48. Jovanovic, S.V.; Simic, M.G. Antioxidants in nutrition. Ann. N. Y. Acad. Sci. 2000, 899, 326-334. [CrossRef] [PubMed]

49. Pedrielli, P.; Skibsted, L.H. Antioxidant synergy and regeneration effect of quercetin, (-)-epicatechin, and (+)-catechin on alpha-tocopherol in homogeneous solutions of peroxidating methyl linoleate. J. Agric. Food Chem. 2002, 50, 7138-7144. [CrossRef] [PubMed]

50. Brownlee, M. Biochemistry and molecular cell biology of diabetic complications. Nature 2001, 414, 813-820. [CrossRef] [PubMed]

51. Li, A.N.; Li, S.; Zhang, Y.J.; Xu, X.R.; Chen, Y.M.; Li, H.B. Resources and biological activities of natural polyphenols. Nutrients 2014, 6, 6020-6047. [CrossRef] [PubMed]

52. Fandrey, J.; Gorr, T.A.; Gassmann, M. Regulating cellular oxygen sensing by hydroxylation. Cardiovasc. Res. 2006, 71, 642-651. [CrossRef] [PubMed]

53. Fiorani, M.; Guidarelli, A.; Blasa, M.; Azzolini, C.; Candiracci, M.; Piatti, E.; Cantoni, O. Mitochondria accumulate large amounts of quercetin: Prevention of mitochondrial damage and release upon oxidation of the extramitochondrial fraction of the flavonoid. J. Nutr. Biochem. 2010, 21, 397-404. [CrossRef] [PubMed]

54. Gorlach, S.; Fichna, J.; Lewandowska, U. Polyphenols as mitochondria-targeted anticancer drugs. Cancer Lett. 2015, 366, 141-149. [CrossRef] [PubMed]

55. Hsu, C.L.; Yen, G.C. Induction of cell apoptosis in 3T3-L1 pre-adipocytes by flavonoids is associated with their antioxidant activity. Mol. Nutr. Food Res. 2006, 50, 1072-1079. [CrossRef] [PubMed]

56. Nichols, M.; Zhang, J.; Polster, B.M.; Elustondo, P.A.; Thirumaran, A.; Pavlov, E.V.; Robertson, G.S. Synergistic neuroprotection by epicatechin and quercetin: Activation of convergent mitochondrial signaling pathways. Neuroscience 2015, 308, 75-94. [CrossRef] [PubMed]

57. De Marchi, U.; Biasutto, L.; Garbisa, S.; Toninello, A.; Zoratti, M. Quercetin can act either as an inhibitor or an inducer of the mitochondrial permeability transition pore: A demonstration of the ambivalent redox character of polyphenols. Biochim. Biophys. Acta 2009, 1787, 1425-1432. [CrossRef] [PubMed]

58. Dorta, D.J.; Pigoso, A.A.; Mingatto, F.E.; Rodrigues, T.; Prado, I.M.; Helena, A.F.; Uyemura, S.A.; Santos, A.C.; Curti, C. The interaction of flavonoids with mitochondria: Effects on energetic processes. Chem. Biol. Interact. 2005, 152, 67-78. [CrossRef] [PubMed]

59. Zhang, X.M.; Chen, J.; Xia, Y.G.; Xu, Q. Apoptosis of murine melanoma B16-BL6 cells induced by quercetin targeting mitochondria, inhibiting expression of PKC-alpha and translocating PKC-delta. Cancer Chemother. Pharmacol. 2005, 55, 251-262. [CrossRef] [PubMed]

60. Yoshino, S.; Hara, A.; Sakakibara, H.; Kawabata, K.; Tokumura, A.; Ishisaka, A.; Kawai, Y.; Terao, J. Effect of quercetin and glucuronide metabolites on the monoamine oxidase-A reaction in mouse brain mitochondria. Nutrition 2011, 27, 847-852. [CrossRef] [PubMed]

61. Vidya, P.R.; Senthil, M.R.; Maitreyi, S.; Ramalingam, K.; Karunagaran, D.; Nagini, S. The flavonoid quercetin induces cell cycle arrest and mitochondria-mediated apoptosis in human cervical cancer (HeLa) cells through p53 induction and NF-kappaB inhibition. Eur. J. Pharmacol. 2010, 649, 84-91. [CrossRef] [PubMed]

62. Psotova, J.; Chlopcikova, S.; Grambal, F.; Simanek, V.; Ulrichova, J. Influence of silymarin and its flavonolignans on doxorubicin-iron induced lipid peroxidation in rat heart microsomes and mitochondria in comparison with quercetin. Phytother. Res. 2002, 16 (Suppl. S1), S63-S67. [CrossRef] [PubMed]

63. Lakroun, Z.; Kebieche, M.; Lahouel, A.; Zama, D.; Desor, F.; Soulimani, R. Oxidative stress and brain mitochondria swelling induced by endosulfan and protective role of quercetin in rat. Environ. Sci. Pollut. Res. Int. 2015, 22, 7776-7781. [CrossRef] [PubMed] 
64. Lagoa, R.; Graziani, I.; Lopez-Sanchez, C.; Garcia-Martinez, V.; Gutierrez-Merino, C. Complex I and cytochrome $\mathrm{c}$ are molecular targets of flavonoids that inhibit hydrogen peroxide production by mitochondria. Biochim. Biophys. Acta 2011, 1807, 1562-1572. [CrossRef] [PubMed]

65. Qureshi, A.A.; Tan, X.; Reis, J.C.; Badr, M.Z.; Papasian, C.J.; Morrison, D.C.; Qureshi, N. Suppression of nitric oxide induction and pro-inflammatory cytokines by novel proteasome inhibitors in various experimental models. Lipids Health Dis. 2011, 10, 177. [CrossRef] [PubMed]

66. Chuang, C.C.; Martinez, K.; Xie, G.; Kennedy, A.; Bumrungpert, A.; Overman, A.; Jia, W.; McIntosh, M.K. Quercetin is equally or more effective than resveratrol in attenuating tumor necrosis factor- $\alpha$-mediated inflammation and insulin resistance in primary human adipocytes. Am. J. Clin. Nutr. 2010, 92, 1511-1521. [CrossRef] [PubMed]

67. Fischer-Posovszky, P.; Newell, F.S.; Wabitsch, M.; Tornqvist, H.E. Human SGBS cells—A unique tool for studies of human fat cell biology. Obes. Facts 2008, 1, 184-189. [CrossRef] [PubMed]

68. Geiger, K.; Muendlein, A.; Stark, N.; Saely, C.H.; Wabitsch, M.; Fraunberger, P.; Drexel, H. Hypoxia induces apelin expression in human adipocytes. Horm. Metab. Res. 2011, 43, 380-385. [CrossRef] [PubMed]

69. Allott, E.H.; Oliver, E.; Lysaght, J.; Gray, S.G.; Reynolds, J.V.; Roche, H.M.; Pidgeon, G.P. The SGBS cell strain as a model for the in vitro study of obesity and cancer. Clin. Transl. Oncol. 2012, 14, 774-782. [CrossRef] [PubMed]

70. Rosenow, A.; Arrey, T.N.; Bouwman, F.G.; Noben, J.P.; Wabitsch, M.; Mariman, E.C.; Karas, M.; Renes, J. Identification of novel human adipocyte secreted proteins by using SGBS cells. J. Proteome Res. 2010, 9, 5389-5401. [CrossRef] [PubMed]

71. Lahnalampi, M.; Heinaniemi, M.; Sinkkonen, L.; Wabitsch, M.; Carlberg, C. Time-resolved expression profiling of the nuclear receptor superfamily in human adipogenesis. PLoS ONE 2010, 5, e12991. [CrossRef] [PubMed]

72. Verstraeten, V.L.; Renes, J.; Ramaekers, F.C.; Kamps, M.; Kuijpers, H.J.; Verheyen, F.; Wabitsch, M.; Steijlen, P.M.; van Steensel, M.A.; Broers, J.L. Reorganization of the nuclear lamina and cytoskeleton in adipogenesis. Histochem. Cell Biol. 2011, 135, 251-261. [CrossRef] [PubMed]

73. Schmidt, S.F.; Jorgensen, M.; Chen, Y.; Nielsen, R.; Sandelin, A.; Mandrup, S. Cross species comparison of $\mathrm{C} /$ EBPalpha and PPARgamma profiles in mouse and human adipocytes reveals interdependent retention of binding sites. BMC Genom. 2011, 12, 152. [CrossRef] [PubMed]

74. Jeninga, E.H.; Bugge, A.; Nielsen, R.; Kersten, S.; Hamers, N.; Dani, C.; Wabitsch, M.; Berger, R.; Stunnenberg, H.G.; Mandrup, S.; et al. Peroxisome proliferator-activated receptor gamma regulates expression of the anti-lipolytic G-protein-coupled receptor 81 (GPR81/Gpr81). J. Biol. Chem. 2009, 284, 26385-26393. [CrossRef] [PubMed]

75. Yao-Borengasser, A.; Monzavi-Karbassi, B.; Hedges, R.A.; Rogers, L.J.; Kadlubar, S.A.; Kieber-Emmons, T. Adipocyte hypoxia promotes epithelial-mesenchymal transition-related gene expression and estrogen receptor-negative phenotype in breast cancer cells. Oncol. Rep. 2015, 33, 2689-2694. [CrossRef] [PubMed]

76. Mack, I.; BelAiba, R.S.; Djordjevic, T.; Gorlach, A.; Hauner, H.; Bader, B.L. Functional analyses reveal the greater potency of preadipocytes compared with adipocytes as endothelial cell activator under normoxia, hypoxia, and TNFalpha exposure. Am. J. Physiol. Endocrinol. Metab. 2009, 297, E735-E748. [CrossRef] [PubMed]

77. Erman, A.; Wabitsch, M.; Goodyer, C.G. Human growth hormone receptor (GHR) expression in obesity: II. Regulation of the human GHR gene by obesity-related factors. Int. J. Obes. (Lond.) 2011, 35, 1520-1529. [CrossRef] [PubMed]

78. Wood, I.S.; Wang, B.; Trayhurn, P. IL-33, a recently identified interleukin-1 gene family member, is expressed in human adipocytes. Biochem. Biophys. Res. Commun. 2009, 384, 105-109. [CrossRef] [PubMed]

79. Rosenow, A.; Noben, J.P.; Bouwman, F.G.; Mariman, E.C.; Renes, J. Hypoxia-mimetic effects in the secretome of human preadipocytes and adipocytes. Biochim. Biophys. Acta 2013, 1834, 2761-2771. [CrossRef] [PubMed]

80. Egert, S.; Wolffram, S.; Bosy-Westphal, A.; Boesch-Saadatmandi, C.; Wagner, A.E.; Frank, J.; Rimbach, G.; Mueller, M.J. Daily quercetin supplementation dose-dependently increases plasma quercetin concentrations in healthy humans. J. Nutr. 2008, 138, 1615-1621. [PubMed] 
81. Guo, Y.; Bruno, R.S. Endogenous and exogenous mediators of quercetin bioavailability. J. Nutr. Biochem. 2015, 26, 201-210. [CrossRef] [PubMed]

82. Nam, J.S.; Sharma, A.R.; Nguyen, L.T.; Chakraborty, C.; Sharma, G.; Lee, S.S. Application of Bioactive Quercetin in Oncotherapy: From Nutrition to Nanomedicine. Molecules 2016, 21, 108. [CrossRef] [PubMed]

(C) 2016 by the authors; licensee MDPI, Basel, Switzerland. This article is an open access article distributed under the terms and conditions of the Creative Commons Attribution (CC-BY) license (http://creativecommons.org/licenses/by/4.0/). 